\title{
PERSPECTIVES ON E-LEARNING
}

\section{Fănel STROE ${ }^{1}$}

\begin{abstract}
E-learning is is one of the biggest challenges of the pandemic. To some extent, it means the perpetuation of today's civilization. I have tried to rethink the e-learning stages of Professor Hubert Dreyfus by looking for new arguments and possible new solutions.
\end{abstract}

Key words: e-learning, sociological imagination, practical wisdom.

\section{Introduction}

Recent changes have put a tremendous pressure on the entire educational system. We had to reinvent the pedagogical work and find or draw new perspectives on the profession, our own image and new goals.

The online teaching system was already operational when the last pandemic began. However, the questions that followed only deepened the thoughts about education and what teachers do with their students.

Along with this debate, joined the debate about how much the internet supports our personal and intellectual development. How useful this current tool is, has always been a question more frequently asked ideologically, than pragmatically.

\section{The dreyfusian stages}

The first step in academic education level is to offer the student perspectives on the field studied. This is achieved by providing the simplest elements, which the student must be able to recognize, master and then use in professional syntax as simply as possible. It is a stage of professional literacy, and the objective of this stage is knowing the concepts and their history. Obviously, the skills acquired by the student at this stage are not easy to acquire, and a good teacher will use plenty of examples to support his or her presentation. The desired result will not be easy to obtain, due to students' tendency to use mainly the short-term memory when sitting in an exam. For a real completion of this stage, the examination must subject the student to a round trip among the simplest concepts and rules, which will help students acquire a professional vocabulary. Understanding would be much more important than memorization, but this pedagogical option must be chosen by the professor.

\footnotetext{
${ }^{1}$ Transilvania University of Braşov, fanel.stroe@unitbv.ro.
} 
What can online learning do at this stage? It raises the level of the didactic act and it facilitates, as a pedagogical tool, an increase of the professionalization of the didactic act. Video conferences have become, out of necessity, a festival of concepts that floods the mind of the student with definitions, rules and examples. The style and identity of the teacher, although they are striking, they are not obvious to the students only by comparison with other teachers and other disciplines. Online learning has made the pedagogical process simpler, more efficient and more goal oriented. Although the online teaching environment is a perfect tool at this stage, for example, by providing links and studying the examples offered in various professional associations, the best exercise for students is to identify on their own those concepts of social sciences that can be used in the analysis of some contemporary social facts. Thus, they could really acquire the abilities required in the first stage of professional literacy.

In the first stage, the students most likely to obtain performance in their studied field will make themselves noticed. Guiding them towards new challenges in front of everyone else will not only stimulate competitiveness within their study group, and will lead to the emergence of the desire for other students to take part in future activities, but it will also become the springboard towards the next stage. The analysis and application of the concepts will lead to the need for a deeper decision-making structure. For example, if in the first stage the student would learn and use the concept of demographic migration, in the present stage, the extension of the interrogative-explanatory field to the extent of connecting the economic opportunities in the destination localities of the migratory phenomenon, leads the student towards improving the professionalization of his abilities in the studied field. Going again through this type of situations by identifying and putting together different pieces of the social puzzle brings about a new need of the student: that of carefully observing if the teacher confirms the analysis of the student, of understanding how an analysis is practically done and how the concepts of social sciences are hierarchized and become practical tools.

We are witnessing, at this stage, the balancing of the importance of online learning towards how the mind of the student watches the whole scene offered by the pedagogical act. Online learning becomes the stage of the didactic act, stage on which the student is invited to perform the first act of his profession, under the careful guidance of the teacher. Obviously, the online learning tool maintains the performance of the pedagogical act, but the key role played by the teacher shapes the mind of the student. Teacher-student interaction is the engine of acquiring professional abilities and online learning is the best technical support we could have ever imagined.

Everything that has been built in the first two stages represents the preliminary steps to achieving a stable level of professional competence. By gaining experience, the student realizes that following the steps in the first two stages requires effort, time and a favorable context for the analysis. If they do not meet these requirements, how could achieve their educational goals? At this point, the teacher may limit the presence of some elements in the presentation board or may introduce false clues to attest the skills of the student. The teacher will ask tricky questions and will invite the student to take part in a theatrical act of competition in order to find out the truth, whose director is 
only the teacher. Apparently, no one is the holder of the truth and all that needs to be done is to identify the questions that lead the student towards achieving exceptional professional competencies. The mastery of the teacher is also given by the ability to play this role of Socratic companion, not only by the ability to select the examples and to decipher rules of the studied field. It is certain that the type of training at this stage becomes different, it turns the student into a more or less experienced seeker. The extreme diversity of the situations which the student is invited to explore can be overcome in the educational process of the student by changing the strategy and inviting the student to a team-work process of learning. Thus, what the teacher sees, the way he builds a perspective in the mind of the student, becomes the educational strategy which helps the student achieve the competence.

In this next stage, online learning may not be the most recommended learning tool. Small technical additions can be used, such as video presentations with open ending, where the student can choose the ending of the studied situation, or exchange the solving perspectives of the field. However, the importance of the role that the teacher plays grows and online learning is beginning to reach its instrumental limits. There is a world of human interaction which overpowers the human-machine interaction. We can take into consideration, for example, the way only art can replicate the interaction between people. Only if online learning retains the artistic features of the educational act can we consider the online learning an efficient tool. On the other hand, online learning becomes less efficient because the binary system $\{0 ; 1\}$, the most common in the construction of the World Wide Web, or the system of the logical decisions that operates with the two values of truth (True; False), is not entirely appropriate, for example, for the grades given by the teacher. At this stage, in addition to the solvingefficiency criteria of the chosen perspective, but rather built by the student, first of all the teacher grades the perspective offered by the student from a creative point of view, and only then from a solving efficiency point of view. The history of millennia of civilization excels in wonder and beauty of thought, which nowadays teachers should never lose sight of. If we ask for innovative solutions from our students, then we should encourage them to own this catharsis.

This moment of initiation into the cultural style of the teacher, of the pauses that the teacher takes in the construction of perspective, is very similar to the creative art of memory of the Middle Ages:

The Art of Memory is a technique for the manipulation of phantasms, which rests on the Aristotelian principle of the absolute precedence of the phantasm over speech and of the phantasmic essence of the intellect [...].The precise inference drawn from it, expounded by St. Thomas in his commentary on Aristotle's De memoria et reminiscentia, is that whatever is seen, thanks to its intrinsic quality of image, is easy to remember, whereas abstract concepts or linguistic sequences require some phantasmic support or other to charge the memory. [...] It is certain that the Art of Memory had been utilized in the Middle Ages in cloisters to foster teaching of abstract concepts but also as a very important element of the monk's inner discipline (Couliano, 1987). 
As an example, students who develop competence by interviewing those who have been or are beneficiaries of a social assistance service, are not willing to take risks in front of the person who is being interviewed. Online learning does not excel at conveying confidence, most of the time the teacher does not manage to break the online barrier in order to inspire courage, commitment, to make the student engange with the person that is being interviewed.

The fourth stage, the one of proficiency, is the stage of the graduate student in the Bachelor's Degree cycle who continues to develop competence beyond theoretical learning. A good example of proficiency is found in social demography laboratories, in detecting the seasonality curve by the student. The intuition of the student, which we could call, without mistake, sociological imagination in the social sciences, begins to develop being put to practical use and the defining word is "burning the stages". The professional intuition of the student is supported by the professional self-awareness of students as they are "a tiny intersection of biography and history in society" (Wright Mills, 2000). This search for the balance between intuition and choosing the theoretical perspective, and respectively, the need for practical performance, is done under pressure most of the time. Even if students always use the professional example of the teacher, which they have in the back of their mind, practical situations require readjustmens, rescaling or new solutions. The professional perfection towards which students reach has these two pillars: the vivid figure and the intuitive way they learned from the teacher and, respectively, the exploration of the shortest and most efficient perspectives innovated by the student. Often, the effort of the student reaches, at this stage, the complexity of the sociological imagination as portrayed by Wright Mills. The importance of this stage is reached only when the student succeeds in intuiting, meaning in building and rebuilding over and over again in their mind, the most efficient possible response option at that moment in time:

They do not possess the quality of mind essential to grasp the interplay of man and society, of biography and history, of self and world. They cannot cope with their personal troubles in such ways as to control the structural transformations that usually lie behind them. [...] The sociological imagination enables its possessor to understand the larger historical scene in terms of its meaning for the inner life and the external career of a variety of individuals. [...] The individual can understand his own experience and gauge his own fate only by locating himself within his period, which he can know his own chances in life only by becoming aware of those of all individuals in his circumstances. [...] We have come to know that every individual live, from one generation to the next, in some society; that he lives out a biography, and that he lives it out within some historical sequence. By the fact of his living he contributes, however minutely, to the shaping of this society and to the course of its history, even as he is made by society and by its historical push and shove. [...]

The sociological imagination enables us to grasp history and biography and the relations between the two within society. (Wright Mills; 2000). 
Instead of a monochrome way, which ultimately cauterizes the style and the identity of the cultural pattern promoted by the teacher, online learning can become an extremely useful tool if it manages to be flexible and an obvious choice at this stage, both as chosen strategy of the student out of different cultural patterns, as well as a way of perpetuation:

The cultural pattern, being produced and acting cognitively and practically in a certain cultural area, creates facilities for getting to know the entire cultural framework, as a sum of values and components of the culture to which [the student] has access, whether known or unknown, this being made possible due to the cognitive capacity [of the student] which ensures the achievement of the cognitive function, both culturally and socially, cultural models which challenge [the student] to get to know the society he lives in (Batâr, 2004).

No matter how hard the educational system tries to keep up with the socio-economic realities, the difficulty of the practical test given to it is very high at the stage of completing the professional expertise of the student. The performance of the two pulsating centers of innovation, the educational system and the big innovative companies, are subject to different registers. "The goal of educational innovation is that of the adaptation of the educational system to the requirements of the development of the way of production, so that a certain type of correspondence would be established between the "product' of education and the way of production" (Vlăsceanu, 1979). This goal often works post factum to innovation in the socio-economic environment. No educational system can develop expertise in an area to be innovated by the big innovative companies ahead of them. The ideal situation for the educational system would be for innovation to take place in this department, and after that to be implemented in the socio-economic environment. However, most of the time, the professional expertise of the student has to face the innovation external to the educational system.

The ability to make more subtle and refined discriminations is what distinguishes the expert from the proficient performer. Among many situations, all seen as similar with respect to a plan or a perspective, the expert has learned to distinguish those situations requiring one reaction from those demanding another. That is, with enough experience in a variety of situations, all seen from the same perspective but requiring different tactical decisions, the brain of the expert gradually decomposes this class of perspectives into subclasses, each of which requires a specific response. This allows the immediate intuitive situational response that is characteristic of expertise (Dreyfus, 2001).

The expert status of the student is undoubtedly an extension of the expertise of the teacher. But beyond sharing the emotion of knowledge, the involvement of the risk in the analyzed situation, or even the stress, transmitted in the expertise stage, the main 
goal of the teacher is to ground the student on the postulates of knowledge and on counterfactual rational constructs. The origin of all these is given to us by Plato:

the individual things necessarily have polar properties: they are beautiful from one point of view, but also ugly from another point of view. Likewise, an individual is big in one aspect and insignificant in another, difficult in one context and light in another, etc. Individuals, multiples or sensibles (take these expressions as equivalents) are therefore 'ambivalent'. What does this 'ambivalence' mean?' [Plato] does not explain clear enough what such a polarity means, apart from a vague image about the object of opinion that it cannot be 'darker' than what it is not and 'clearer' than what it exists. This metaphor of light will always be found in the metaphysical discourse of Plato on the degrees of reality or aletheia that the mind of the philosopher must pierce. Hence the Heideggerian translation of the term 'aletheia - not being hidden', a word that has degrees of comparison: the object of opinion is more hidden than the object of ignorance, but more hidden than that of science (apud Mureșan, 2006).

I therefore believe that online learning at this stage, through the means at its disposal, can be the most appropriate pedagogical tool. Achieving these high performances depends, on the one hand, on the cooperation between the IT field and the pedagogical field and, on the other hand, on the talent of the teacher to explain to the IT engineer the objectives of this stage. In search of an identity of one's own expertise, another advantage of online learning is that it facilitates the connection of students with other teachers who have different styles from their first teacher. The network characteristics of online learning are fully appropriate for this stage, which allows the equidistant study of different teaching styles and the shaping of the expertise of the student.

Mastery, the last stage in the training of students is the stage where students do what they have to do, at the right time and in the right way. The oriental tradition considers experience to be the path to mastery and recommends a constant increase in the number of cases studied. But Aristotle speaks of the study of practical wisdom, which seeks "the contingent particular actions and because of that it is not a necessary knowledge, a 'science', but a probable knowledge, a 'right deliberation' about what we need to do" (apud Mureșan, 2007). Only by adding a right purpose and desire can we talk about 'phronesis', the practical wisdom. We have the metaphor of the rose of Paracelsus which draws attention precisely to this need for concordance between the right purpose and the right desire. Although the power of the word of a master can bring a whole world to life, he refuses to testify in the face of inappropriate passions or vices: "Paracelsus was the alone. Before putting out the lamp and returning to his weary chair, he poured the delicate fistful of ashes from one hand into the concave other, and he whispered a single word. The rose appeared again" (Borges, 1999).

Mastery as practical wisdom is the act of deliberate choice, prohairestai. Such an act is mentioned by Hesse when he speaks about the vocation of a teacher: 
but we seem almost to have forgotten the original meaning of the title 'Magister Ludi', for it does not signify the high speciality to which we have fitted the word. In its original sense Magister Ludi simply meant schoolmaster [...]. Above all else we need teachers, men who will bring to our youth the capacity for moderation and judgment and who, by their example, will instil a reverence for truth, obedience to the spirit and service to the word (Hesse, 1957).

\section{Conclusions}

As Foucault said, "After all, what would be the value of the passion for knowledge if it resulted only in a certain amount of knowledgeableness and not, in one way or another and to the extent possible, in the knower's straying afield of himself? There are times in life when the question of knowing if one can think differently than one thinks, and perceive differently than one sees, is absolutely necessary if one is to go on looking and reflecting at all" (Foucault, 2020). Obviously, e-learning is not an ideal learning situation for anyone. But never the stakes of human progress have not been auctioned in ideal situations. The teacher's destiny is like the one Faust had:

He only earns his freedom, life itself,

Who daily strives to conquer it anew (Goethe, 2014).

Starting with 2016, we were warned that "technology and digitization will revolutionize everything, making the overused and often ill-used adage 'this time is different' apt. Simply put, major technological innovations are on the brink of fueling momentous change throughout the world" (Schwab, 2016). This year, the great reset changed everything "almost instantly, most things becoming "e-things": e-learning, ecommerce, e-gaming, e-books, e-attendance [...] many of the tech behaviours that we were forced to adopt during confinement will through familiarity become more natural" (Schwab, 2020). Perhaps we don't fully appreciate all the benefits of e-learning yet, which are: safer, cheaper, greener and more convenient.

How could the teacher keep the fulfilling character of e-learning? And how could we define this implicit character of e-learning?

The implicit [...] is what is implied in the fact of being caught up in the game, in the illusio understood as a fundamental belief in the interest of the game and the value of the stakes which is inherent in that membership. Entry into a scholastic universe presupposes a suspension of the presuppositions of common sense and a paradoxal commitment to a more or less radically new set of presuppositions, linked to the discovery of stakes and demands neither known nor understood by ordinary experience. Each field is characterized by the pursuit of a specific goal, tending to favour no less absolute investments by all [...] those who possess the required dispositions (for example, libido sciendi). Taking part in the illusio - scientific, literary, philosophical or other - means taking seriously [...] stakes which, arising from the logic of the game itself, establish its 'seriousness' [...]. (Bourdieu, 2018). 
For example, as Kathleen Nolan concludes in her own study, the teachers can make a change when there is a disjunction between habitus and current conditions. Precisely because it is an unending game, with a potential for permanent change, uncertainty can extract the character of fulfilling (Nolan, 2016). In their turn, Costa and Murphy believe that the teacher can extract "self reflexivity which in the last instance will provide her with knowledge about what needs to be changed" and, also, teacher should do the same way as "Nolan [whom] concerns herself with how best to develop a mechanism of self-analysis that may trigger change in the self" (Murphy, M., Costa, C., 2016).

What we might expect from online learning in this period is perhaps what we might once hope to achieve from artificial intelligence, namely to be like humans, as Yeats says in one of his last letters: "Man can embody truth but he cannot know it" (Yeats, 1954).

\section{References}

Batâr, D. (2004). Instituționalitatea modelelor culturale [The Institutionality of Cultural Models]. Sibiu: Lucian Blaga University Publishing House.

Borges, J. L. (1999). Collected Fictions. New York: Penguin Books.

Bourdieu, P. (2018). Pascalian Meditations. Cambridge: Polity Press.

Couliano, I. P. (1987). Eros and Magic in the Renaissance. Chicago: University of Chicago Press.

Dreyfus, H. L. (2001). On the Internet. New York: Routledge.

Foucault, M. (2020). The History of Sexuality, Volume 2: The Use of Pleasure. London: Penguin Books Ltd.

Goethe, J. W. v. (2014). Faust. A Tragedy. New Haven and London: Yale University Press. Hesse, H. (1957). Magister Ludi. New York: Frederick Ungar Publishing Co.

Mureșan, V. (2006). Comentariu la Republica lui Platon [Commentary on Plato's Republic]. Bucharest: Paideia.

Mureșan, V. (2007). Comentariu la Etica Nicomahică [Commentary on Nicomachean Ethics]. Bucharest: Humanitas.

Murphy, M., Costa, C., (2016). Method as theory - (re)exploring the intellectual context of education research. In M. Murphy, C. Costa (Eds.), Theory as Method in Research. On Bourdieu, social theory and education (pp. 191-199). London and New York: Routledge.

Nolan, K. (2016). Stimulating conversations between theory and methodology in mathematics teacher education research. Inviting Bourdieu into self-study research. In M. Murphy, C. Costa (Eds.), Theory as Method in Research. On Bourdieu, social theory and education (pp. 171-190). London and New York: Routledge.

Schwab, K. (2016). The Fourth Industrial Revolution. Geneva: World Economic Forum. Schwab, K., Malleret, T. (2020). COVID-19: The Great Reset. Geneva: World Economic Forum. Vlăsceanu, L. (1979). Decizie și inovație în învățământ [Decision and Innovation in Education]. Bucharest: Didactic and Pedagogical Publishing House.

Wright Mills, C. (2000). The Sociological Imagination. Oxford: Oxford University Press. Yeats, W. B. (1954). The Letters of W. B. Yeats. London: Ruper Hart-Davis Ltd. 